\title{
Author Index Volume 15 (1996)
}

The issue number is given in front of the pagination

Editorial: Asset optimization and multi-resource planning (3) 153-156

Editorial: Customer-specific value chain: beyond mass customization? (2) 93-98

Editorial: Rethinking optimality: eight concepts (1) $1-4$

Editorial: Knowledge as coordination of action (4) $211-213$

Bakken, B.E., see Midttun, A. (3) 187-200

Bär, F.L. and F.A.P. Fialho, Taylorism and quality control management in Brazil (4) 227-233

Benedetti, E. and S. Solari, Evolutionary systems and long run economics (2) 125-133

Bolwijn, P.T. and T. Kumpe, About facts, fiction and forces in Human Resource Management (3) 161172

Busby, J.S., Comment: Optimism and calibration in risk assessment: a note reply to Hartz and Elrod (4) $257-261$

Coman, A., Competence, power and conflict in group decision making (4) 245-255

Conti, R.F. and M. Warner, Technology, teams and Theories of the Firm (2) 101-112

Elrod, R., see Hartz, C. (1) 79-83

Fialho, F.A.P., see Bär, F.L. (4) 227-233

Foss, N.J., Firms, incomplete contracts, and organizational learning (1) 17-26

Hartz, C. and R. Elrod, The role of optimism in the probabilistic assessment of risk: A second look at calibration of probabilities (1) 79-83

Jacobson, R., The real work of teams (1) 71-78

Jordan, L.G., Strategic control in reengineering the complex organization (4) 219-225

Katsioloudes, M.I., Socio-technical analysis: a normative model for participatory planning (4) 235243
Kline, T.J.B., M. MacLeod and J.-L. McGrath, Team effectiveness: contributors and hindrances (3) 183186

Kumpe, T., see Bolwijn, P.T. (3) 161-172

Machado, N., Incongruence and tensions in complex organizations: The case of an organ transplantation system (1) $55-70$

MacLeod, M., see Kline, T.J.B. (3) 183-186

Maruyama, M., Editorial comment: Young Hungarian managers in foreign joint-venture firms (3) 201207

Maruyama, M., Editorial comments: Post-totalitarian deconversion trauma, and Bribing in historial context: the case of Japan (2) 135-142

Mathews, J., Holonic organisational architectures (1) 27-54

Mathews, J., Organizational foundations of economic learning (2) 113-124

McGrath, J.-L., see Kline, T.J.B. (3) 183-186

Midttun, A., B.E. Bakken and F. Wenstøp, Rational, emotional and normfollowing actors and liberal free trade in the Norwegian electricity market (3) $187-200$

Nodoushani, O. and P.A. Nodoushani, Rethinking the future of management education (3) 173-181

Nodoushani, O. and P.A. Nodoushani, Special book review: Lean and Mean: The Changing Landscape of Corporate Power in the Age of Flexibility (2) 143-146

Nodoushani, P.A., see Nodoushani, O. (2) 143-146

Nodoushani, P.A., see Nodoushani, O. (3) 173-181

Ronen, B., Reengineering: Dangers and caution needed (1) 9-15

Solari, S., see Benedetti, E. (2) $125-133$

Warner, M., see Conti, R.F. (2) 101-112

Wenst $\varnothing$ p, F., see Midttun, A. (3) 187-200 